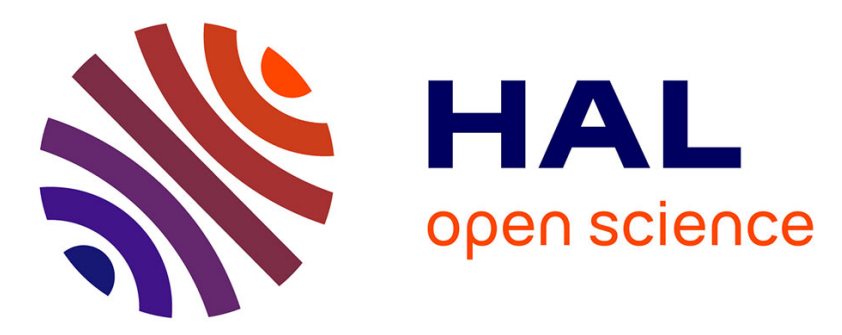

\title{
Synchronous Strengthening of the Indian and East Asian Monsoons in Response to Global Warming Since the Last Deglaciation
}

Wenying Jiang, Suzanne Leroy, Shiling Yang, Enlou Zhang, Luo Wang, Xiaoxiao Yang, Patrick Rioual

\section{To cite this version:}

Wenying Jiang, Suzanne Leroy, Shiling Yang, Enlou Zhang, Luo Wang, et al.. Synchronous Strengthening of the Indian and East Asian Monsoons in Response to Global Warming Since the Last Deglaciation. Geophysical Research Letters, 2019, 46 (7), pp.3944-3952. 10.1029/2019GL082084. hal02546062

\section{HAL Id: hal-02546062 \\ https://hal.science/hal-02546062}

Submitted on 17 Apr 2020

HAL is a multi-disciplinary open access archive for the deposit and dissemination of scientific research documents, whether they are published or not. The documents may come from teaching and research institutions in France or abroad, or from public or private research centers.
L'archive ouverte pluridisciplinaire HAL, est destinée au dépôt et à la diffusion de documents scientifiques de niveau recherche, publiés ou non, émanant des établissements d'enseignement et de recherche français ou étrangers, des laboratoires publics ou privés. 


\section{Geophysical Research Letters}

\author{
RESEARCH LETTER \\ 10.1029/2019GL082084 \\ Key Points: \\ - Pollen data show a minimum 650-m \\ upward migration of the Tsuga \\ dumosa forest zone in the Hengduan \\ Mountains from 18.6 to $7.1 \mathrm{kyr}$ BP \\ - Our data and a synthesis of 37 \\ additional paleovegetation records \\ show the peak of the Holocene \\ Climate Optimum occurring around \\ 7 kyr BP \\ - The Indian and East Asian summer \\ monsoons strengthened \\ synchronously in response to past \\ global warming
}

Supporting Information: - Supporting Information S1

Correspondence to:

W. Jiang,

wjiang@mail.iggcas.ac.cn

Citation:

Jiang, W., Leroy, S. A. G., Yang, S. Zhang, E., Wang, L., Yang, X., \& Rioual, P. (2019). Synchronous strengthening of the Indian and East Asian monsoons in response to global warming since the last deglaciation. Geophysical Research Letters, 46, 3944-3952. https://doi.org/10.1029/ 2019GL082084

Received 16 JAN 2019 Accepted 20 MAR 2019 Accepted article online 22 MAR 2019 Published online 4 APR 2019

\section{Synchronous Strengthening of the Indian and East Asian Monsoons in Response to Global Warming Since the Last Deglaciation}

\author{
Wenying Jiang ${ }^{1,2} \mathbb{D}$, Suzanne A.G. Leroy ${ }^{3}$ (D) Shiling Yang ${ }^{1,4,5}$ (D), Enlou Zhang ${ }^{6}$ (D), \\ Luo Wang ${ }^{1,2}$ (D) Xiaoxiao Yang ${ }^{1,5}$, and Patrick Rioual ${ }^{1,4}$ iD \\ ${ }^{1}$ Key Laboratory of Cenozoic Geology and Environment, Institute of Geology and Geophysics, Chinese Academy of \\ Sciences, Beijing, China, ${ }^{2}$ Institutions of Earth Science, Chinese Academy of Sciences, Beijing, China, ${ }^{3}$ Aix Marseille \\ University, CNRS, Minist Culture, LAMPEA, UMR 7269, Aix-en-Provence, France, ${ }^{4}$ CAS Center for Excellence in Life and \\ Paleoenvironment, Beijing, China, ${ }^{5}$ College of Earth and Planetary Sciences, University of Chinese Academy of Sciences, \\ Beijing, China, ${ }^{6}$ State Key Laboratory of Lake Science and Environment, Nanjing Institute of Geography and Limnology, \\ Chinese Academy of Sciences, Nanjing, China
}

Abstract The responses of the Indian and East Asian summer monsoons (ISM and EASM) to warming since the last deglaciation are controversial. Pollen results from a subalpine lake in the ISM area show that the Tsuga dumosa forest zone migrated at least $650 \mathrm{~m}$ upward during 18.6-7.1 kyr BP, indicating a gradual rise in mean annual temperature exceeding $3.9^{\circ} \mathrm{C}$. In response, grasses and deciduous and evergreen broad-leaved trees successively colonized the mountainous environment. By contrast, the area around a lake in the EASM area was gradually occupied by temperate deciduous trees. In both areas, the maximum monsoonal precipitation occurred during 7.1-6.4 kyr BP, coinciding with peak Holocene warmth, but lagging the peak in Northern Hemisphere summer insolation by 3.9-4.6 kyr, due to delayed ice melting in northern high latitudes. Our results indicate the synchronous strengthening of the ISM and EASM in response to warming-induced northward shifts in the Intertropical Convergence Zone.

Plain Language Summary The responses of the Indian summer monsoon (ISM) and East Asian summer monsoon to past global warming provide valuable insights into future climate scenarios. A paleovegetation reconstruction from the ISM area shows a gradual warming of over $3.9^{\circ} \mathrm{C}$ in mean annual temperature from 18.6 to $7.1 \mathrm{kyr} \mathrm{BP}$. The ISM and East Asian summer monsoon strengthened synchronously in response to warming-induced shifts in the Intertropical Convergence Zone and reached their peak at 7.1-6.4 kyr BP, lagging the summer insolation maximum by 3.9-4.6 kyr, due to delayed ice melting in northern high latitudes. As future warming continues, the loss of habitat for Tsuga dumosa and other alpine species will accelerate in the ISM area, and the abundance of deciduous trees will increase in northern China.

\section{Introduction}

Understanding the dynamics and variability of the Indian summer monsoon (ISM) and the East Asian summer monsoon (EASM) since the last deglaciation is crucial for developing accurate projections of future climatic conditions (Broecker \& Putnam, 2013). However, the spatiotemporal patterns of the ISM and the EASM are debated. Some have argued for the asynchronous evolution of the ISM and the EASM, in terms of the onset of the Holocene Climate Optimum and the timing of peak Holocene warmth (An et al., 2000; Herzschuh et al., 2006; Hong et al., 2005; Wang et al., 2010; Zhou et al., 2016), emphasizing the dominance of processes internal to the climate system. By contrast, others have documented roughly synchronous changes in the ISM and the EASM (Cheng et al., 2012; Dong et al., 2010; Zhang et al., 2013), pointing to primacy of insolation forcing of the Asian monsoon system. This discrepancy may be due to the use of diverse physical, chemical, and biological proxy records from various geological archives, with variable temporal resolutions, many of which are only indirect measures of monsoon rainfall. However, comparison of the variability of the ISM and the EASM, assessed using a single direct measure, arguably provides the soundest basis for understanding monsoon dynamics.

Here we present vegetation reconstructions from two lake sediment cores, based on pollen-based plant functional types (PFTs; Prentice et al., 1996; Yu et al., 2000), a robust method for measuring palaeomonsoon 


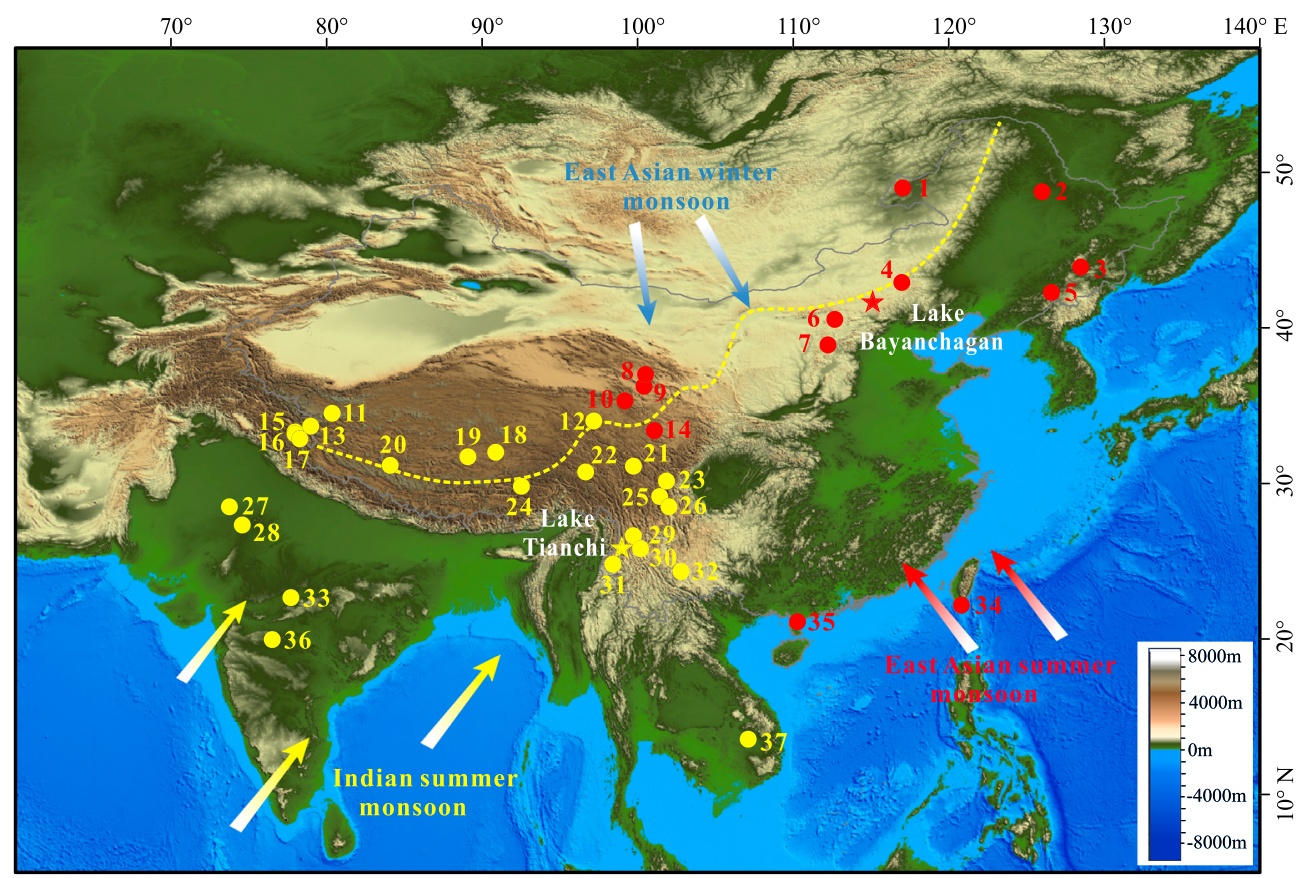

Figure 1. Study sites and monsoon pathways. The yellow star indicates Lake Tianchi, and the red star indicates Lake Bayanchagan. Solid circles with numbers indicate the locations of lakes for which previously published palaeomonsoon records (Table S1; Chen et al., 2014, 2015; Cheng et al., 2013; Demske et al., 2009; Enzel et al., 1999; Herzschuh et al., 2006, 2009, 2014; Jarvis, 1993; Kramer et al., 2010; Lee et al., 2010; Leipe et al., 2014; Li et al., 2011; Ma et al., 2014; Maxwell, 2001; Prasad et al., 2014; Quamar \& Chauhan, 2012; Shen et al., 2005, 2006; Singh et al., 1990; Stebich et al., 2015; Sun et al., 1993, 2016; Tang et al., 2000; VanCampo et al., 1996; VanCampo \& Gasse, 1993; Wang et al., 2007; Wen et al., 2010, 2017; Wischnewski et al., 2011; Wunnemann et al., 2010; Xiao et al., 2004, 2014, 2015; Zhang et al., 2016; Zhou et al., 2016) for the Indian summer monsoon area (yellow) or the East Asian summer monsoon area (red) were used in our combined analysis. The yellow dashed line indicates the northern limit of the modern Asian summer monsoon (Jiang, 2013). The arrows depict the directions of monsoon winds.

intensity. The core from the ISM area is from Lake Tianchi (Figure 1) in the Hengduan Mountains, Yunnan Province, southern China, and covers the last $18.6 \mathrm{kyr}$. The core from the EASM area is from Lake Bayanchagan (Figure 1) in Inner Mongolia, northern China, and covers the last $11.5 \mathrm{kyr}$. We also conducted an analysis and synthesis of previously published palaeovegetation data obtained from lake sediments throughout the Asian summer monsoon (ASM) domain, with the aim of determining the spatiotemporal patterns of the ISM and the EASM and their respective mechanisms.

\section{Materials and Methods}

The mean annual temperature and annual precipitation are about $10.7^{\circ} \mathrm{C}$ and $920 \mathrm{~mm}$ for Lake Tianchi and about $3{ }^{\circ} \mathrm{C}$ and $350 \mathrm{~mm}$ for Lake Bayanchagan. Most of the precipitation occurs in summer (June to September). The present-day vegetation in the region of Lake Tianchi has a zoned distribution with elevation: from low to high elevation along an altitudinal gradient ( 700 to $\sim 4,000 \mathrm{~m}$ above sea level [a.s.l.]), the vegetation is successively characterized by monsoon rainforest $(<\sim 1,500 \mathrm{~m}$ a.s.l.), subtropical broadleaved evergreen forest ( 1,500- 2,100 $\mathrm{m}$ a.s.l.), midmontane moist broad-leaved evergreen forest ( 2,100- 2,600 m a.s.l.), Tsuga dumosa stands mixed with other coniferous species and broad-leaved forest ( 2,600- 3,100 $\mathrm{m}$ a.s.l.), coniferous forest $(\sim 3,100-\sim 3,700 \mathrm{~m}$ a.s.l.), and alpine shrubs and meadows (> 3700 m a.s.l.; Editorial Committee of Vegetation Map of China, CAS, 2007). These changes reflect the steep vertical gradients in temperature and precipitation. In the region of Lake Bayanchagan, steppe is currently the dominant vegetation.

Core YL (10.69-m long; $25^{\circ} 52.4^{\prime} \mathrm{N}, 99^{\circ} 16.8^{\prime} \mathrm{E}, 2,550 \mathrm{~m}$ a.s.l.) from Lake Tianchi was recovered from a water depth of $14 \mathrm{~m}$ (Figures S1a and S1b in the supporting information). An age model was created using 20 AMS ${ }^{14} \mathrm{C}$ dates processed using the Bacon age-modeling software (Blaauw \& Christen, 2011; Table S2 and 


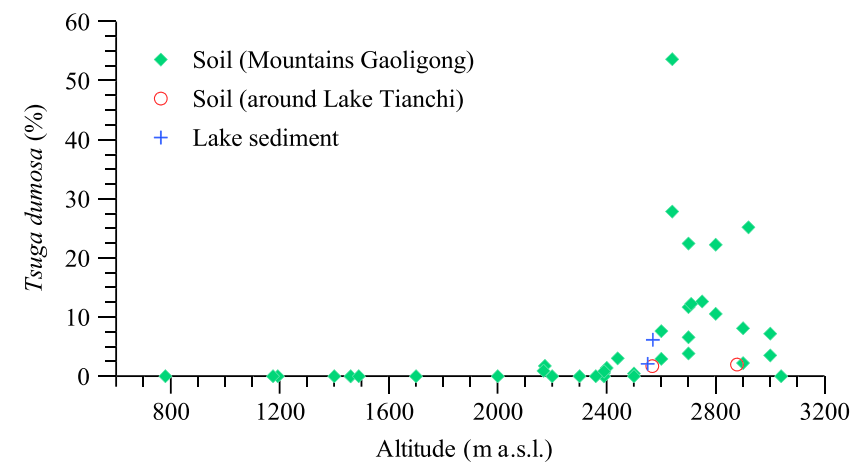

Figure 2. Variations in Tsuga dumosa pollen percentages of modern surface soils along an altitudinal transect in the Hengduan Mountains.
Figure S2a). Core BY (1.8-m long; $41^{\circ} 39^{\prime} \mathrm{N}, 115^{\circ} 12.6^{\prime} \mathrm{E}, 1,355 \mathrm{~m}$ a.s.l.) was collected from a trench at the center of Lake Bayanchagan (Figure 1). The lake is almost completely dry at present due to human activity, although shallow patches of water are maintained by summer rainfall. An age model was previously established for the core based on seven AMS ${ }^{14} \mathrm{C}$ dates (Jiang et al., 2006; Table S3 and Figure S2b).

In total, 98 samples were selected for pollen analysis: 45 and 53 samples from surface soils in the Hengduan Mountains (Figures S1c-S1f and Table S4) and from core YL, respectively. Pollen grains were concentrated using HF treatment (Faegri et al., 2000) and identified at $\times 400$ magnification using an optical microscope. Between 470 and 680 terrestrial pollen grains were counted for each fossil sample, and 200 to 500 grains were counted for most modern samples. Pollen diagrams were drawn using Psimpoll 4.25 (Bennett, 2005; Figures S3 and S4). PFTs scores were calculated using the PPPBASE software package (Guiot \& Goeury, 1996). Vegetation changes were then reconstructed based on the affinity scores for steppe vegetation and deciduous evergreen and coniferous trees. In addition, total carbon and total nitrogen (Figure S5) were determined for 262 samples from Lake Tianchi using a Euro 3000 Elemental Analyzer. All samples were treated with 1-M HCl to remove inorganic carbonate prior to measurement.

\section{Pollen Data}

\subsection{Pollen Assemblages in Modern Soils}

The relationship between the eight vegetation types and pollen assemblages (Table S4) shows that T. dumosa pollen has a low dispersal ability (Figure S3). For modern soil samples collected under T. dumosa stands mixed with other coniferous species and broad-leaved forest (Nos. 2-16), T. dumosa pollen is abundant, ranging from $3 \%$ to $54 \%$. In soils collected from midmontane moist broad-leaved evergreen forest (Nos. 17-31) and Pinus yunnanensis forest (Nos. 43-44), the values of T. dumosa pollen decrease to $<8 \%$ and $<2 \%$, respectively. T. dumosa pollen is rare or absent in soil samples collected in northern tropical mountainous monsoon rainforest (Nos. 41-42), subtropical broad-leaved evergreen forest (Nos. 32-33, 38-39), subtropical valley rainforest (Nos. 34-37), xeromorphic scrub vegetation (No. 40), and dwarf (Rhododendron) forest (No. 1).

Surveys of surface soils along an altitudinal transect (Table S4 and Figure 2) show that T. dumosa pollen percentages reach $3-50 \%$ (average $\sim 11 \%$ ) in samples collected under T. dumosa stands mixed with other coniferous species and broad-leaved forest (2,600-3,000 $\mathrm{m}$ a.s.1.); the percentages decrease to 0-7\% (average $<2 \%$ ) in samples collected within a vertical distance of $200 \mathrm{~m}$ from the mixed forest and to $\sim 0 \%$ at distances exceeding $200 \mathrm{~m}$. In a sediment sample collected from a stream flowing into Lake Tianchi, below the $T$. dumosa zone, the $T$. dumosa pollen content reaches $6.17 \%$, implying that it can be transported comparatively long distances by water.

\subsection{Pollen Assemblages From Core YL From Lake Tianchi}

Forests have dominated the area surrounding Lake Tianchi for the past $18.6 \mathrm{kyr}$ (Figure S4). Pollen zones YL-1 and YL-2 (18.6-15.9 kyr BP) are characterized by broad-leaved forest with Betula, Quercus, Castanopsis, Salix, and Ulmus-Zelkova. Mixed coniferous (Abies, Picea, and Pinus) and broad-leaved (Alnus, Betula, Quercus, Castanopsis, and Ulmus-Zelkova) forest occurred between 15.9 and $10.3 \mathrm{kyr} \mathrm{BP}$ (YL-3 to YL-4). During the early to mid-Holocene (YL-5, 10.3-3.2 kyr BP), mixed coniferous (T. dumosa and Pinus) and broad-leaved (Alnus, Betula, Cyclobalanopsis, Quercus, and Castanopsis) forests were present. The late Holocene (YL-6, 3.2 kyr BP to present) was characterized by mixed Pinus, Alnus, and Quercus forests.

\subsection{Pollen Assemblages From Core BY From Lake Bayanchagan}

The original pollen data for core BY were published in Jiang et al. (2006). Steppe vegetation has dominated the area around Lake Bayanchagan over the past $11.5 \mathrm{kyr}$ (Figure S6). Pollen zone BY-1 ( 11.5-7.4 kyr) is characterized by a gradual decrease in Artemisia and by increases in Quercus and Pinus. The maximum 
abundances of broad-leaved trees (Betula, Quercus, Corylus, Ostryopsis, and Ulmus) occurred between 7.4 and 5.9 kyr BP (BY-2). Patches of coniferous (Abies and Pinus) and broad-leaved (Betula and Ulmus) forest were present between 5.9 and $4.5 \mathrm{kyr}$ BP (BY-3). Pollen zone BY-4 (4.5-2 kyr BP) is characterized by increases in Poaceae and Chenopodiaceae and a decrease in Pinus. During the late Holocene (BY-5 and BY-6, 2 kyr BP to present), the trees almost disappeared. Vegetation consisted mainly of Artemisia, Poaceae, and Chenopodiaceae.

\section{Results and Discussion}

In the Hengduan Mountains of the ISM area, Tsuga is temperature sensitive (Li et al., 2013), thus enabling palaeotemperature reconstruction based on pollen records. Modern investigations demonstrate that T. dumosa, a local species, occurs today at elevations of 2,300-3,500 m a.s.l. in the Hengduan Mountains, and its optimum elevation within the study area is 2,600-3,000 m a.s.l. (Editorial Committee of Vegetation Map of China, 2007; Li et al., 2013). Because T. dumosa pollen is large (60-110 $\mu \mathrm{m})$ and heavy (Wang et al., 1997), our surveys of surface soils along an altitudinal transect show that it can be transported from the T. dumosa zone over a vertical distance of $<200 \mathrm{~m}$ by wind and over large distances by water (Table S4 and Figure 2). Thus, the T. dumosa pollen preserved in the sediments of Lake Tianchi is mainly wind transported when the T. dumosa forest zone was located below the lake (2,550 $\mathrm{m}$ a.s.l.); however, it was transported by both wind and water when the forest zone was above the lake.

The limited dispersal ability of T. dumosa pollen permits a precise assessment of the vertical movements of the T. dumosa forest zone and the associated temperature changes. Pollen data from Lake Tianchi show that T. dumosa pollen were nearly absent between 18.6 and $16 \mathrm{kyr} \mathrm{BP}$ and rare $(<2 \%)$ from 16 to $12 \mathrm{kyr} \mathrm{BP}$ (Figure 3a), indicating that the upper limit of the mixed T. dumosa forest zone was below 2,350 $\mathrm{m}$ a.s.l. from 18.6 to $12 \mathrm{kyr}$ BP (given the 200-m dispersal distance of its pollen; Figure 2). After $12 \mathrm{kyr}$ BP, the content of T. dumosa pollen gradually increased, peaking at $17 \%$ at $7.1 \mathrm{kyr}$ BP before commencing a decreasing trend (Figure 3a). This indicates an upward movement of the T. dumosa forest zone during the early and mid-Holocene, in response to warming. Since the mid-Holocene was warmer than today (Marcott et al., 2013), the upper optimum elevation of the T. dumosa forest zone was slightly higher than the current level (3,000 $\mathrm{m}$ a.s.l.). Thus, we derive a minimum upward migration distance of $650 \mathrm{~m}$ for T. dumosa forest from the last deglaciation to the mid-Holocene. Assuming a lapse rate of $0.6{ }^{\circ} \mathrm{C}$ for every $100 \mathrm{~m}$ of elevation change (Domros \& Peng, 1988; Lenoir et al., 2008), this upward shift of the vegetation zone indicates an increase in mean annual temperature of at least $3.9^{\circ} \mathrm{C}$ from 18.6 to $7.1 \mathrm{kyr} \mathrm{BP}$. The magnitude of the temperature change during this interval is consistent with estimates obtained in other low-latitude areas (Porter, 2001; Weijers et al., 2007).

Vegetation reconstructions show that, although forest plants have dominated the Lake Tianchi area over the past $18.6 \mathrm{kyr}$, successive colonization of different vegetation communities has occurred (Figures 3b-3f): grass and temperate deciduous trees dominated from 18.6 to $15 \mathrm{kyr} \mathrm{BP}$, warm temperate deciduous trees from 15 to $8 \mathrm{kyr} \mathrm{BP}$, and finally, warm temperate coniferous forest and subtropical evergreen forest dominated from 10 to $4 \mathrm{kyr} \mathrm{BP}$ and peaked at 7.1 and 6.4 kyr BP, respectively. The increase in subtropical evergreen forest during the early to mid-Holocene is consistent with the high carbon/nitrogen $(\mathrm{C} / \mathrm{N})$ ratios of the lake sediments (Figure 3g), which suggest the increased input of terrestrial organic matter into the lake, resulting from increased vegetation productivity. All of these records indicate a progressively warmer and wetter climate, reflecting a trend of increasing ISM intensity, from the last deglaciation until the mid-Holocene.

Vegetation results for Lake Bayanchagan in the EASM area (Figures 3h-3k) show that, although steppe vegetation dominated over the past $\sim 11.5 \mathrm{kyr} \mathrm{BP}$, it decreased from 11 to $6 \mathrm{kyr} \mathrm{BP}$, whereas temperate deciduous forest gradually increased from 10.5 to $6.8 \mathrm{kyr}$ BP before decreasing and finally disappearing at approximately 6 kyr BP. Maximum abundance of cool temperate deciduous trees occurred between 10.5 and $5.5 \mathrm{kyr}$ $\mathrm{BP}$, and desert vegetation increased gradually after $6 \mathrm{kyr}$ BP. The increase in deciduous (cool temperate and temperate) forest is consistent with the low $\delta^{18} \mathrm{O}$ values of authigenic carbonate from the same core (Figure 31), which resulted from increased monsoonal precipitation and decreased evaporation (Jiang \& Liu, 2007). This evidence indicates the occurrence of warm, humid climatic conditions from 10.5 to $5.5 \mathrm{kyr} \mathrm{BP}$ - the period which includes the Holocene Optimum peak at $6.8 \mathrm{kyr}$ BP. 


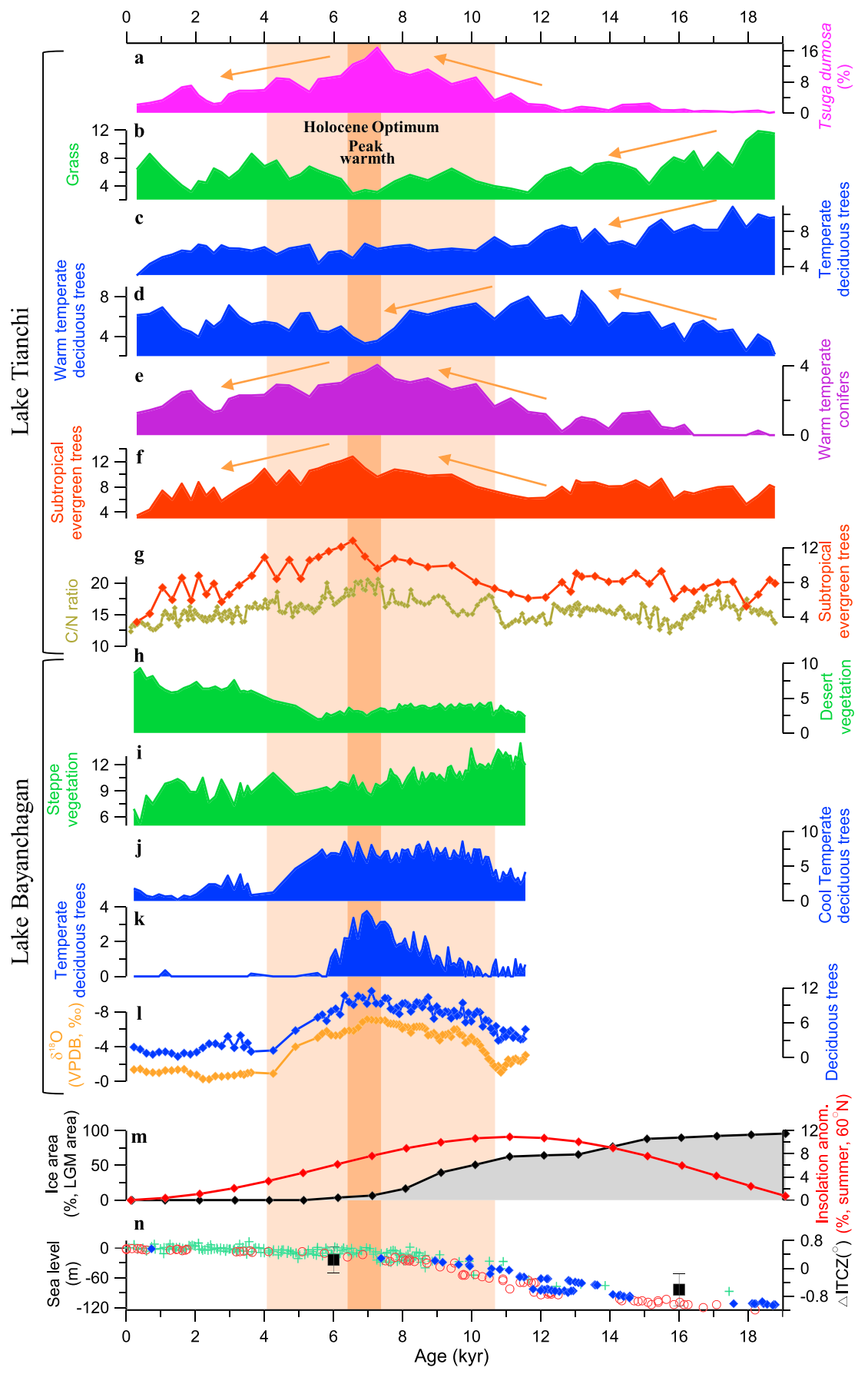

Figure 3. Fossil pollen-based vegetation records from Lake Tianchi (a-g) and Lake Bayanchagan (h-l) and comparison with records of summer insolation anomalies $(\mathrm{m})$, the area of the Laurentide ice sheet $(\mathrm{m})$, and global sea-level changes (n). (a-g) Changes in Tsuga dumosa forest (a), grassland (b), temperate deciduous forest (c), warm temperate deciduous forest (d), warm temperate coniferous forest (e), evergreen forest (f), and a comparison of evergreen forest (red) and $\mathrm{C} / \mathrm{N}$ ratios (olive; g) over the past $18.6 \mathrm{kyr}$ at Lake Tianchi in southern China. (h-l) Changes in desert vegetation (h), steppe vegetation (i), cool temperate deciduous forest (j), temperate deciduous forest (k), and a comparison of deciduous forest (blue), and $\delta^{18} \mathrm{O}$ of authigenic carbonate (orange; l) over the past $11.5 \mathrm{kyr}$ at Lake Bayanchagan in northern China (Jiang et al., 2006). All vegetation records are plotted as plant functional type scores, except that of Tsuga dumosa. (m) Summer insolation anomalies at $60^{\circ} \mathrm{N}$ (Berger \& Loutre, 1991; red), and the area of the Laurentide ice sheet, expressed as a fraction of the LGM Laurentide ice area (Shuman et al., 2005) (black). (n) Sea level (Barbados sea level: blue diamonds (Peltier \& Fairbanks, 2006) and red circles (Fairbanks, 1990); Red Sea level: green plus signs (Grant et al., 2012) and mean ITCZ location (black squares) relative to today (McGee et al., 2014). Vertical shaded bars correspond to the Holocene Optimum (light orange) and its peak (orange). ITCZ = Intertropical Convergence Zone. 


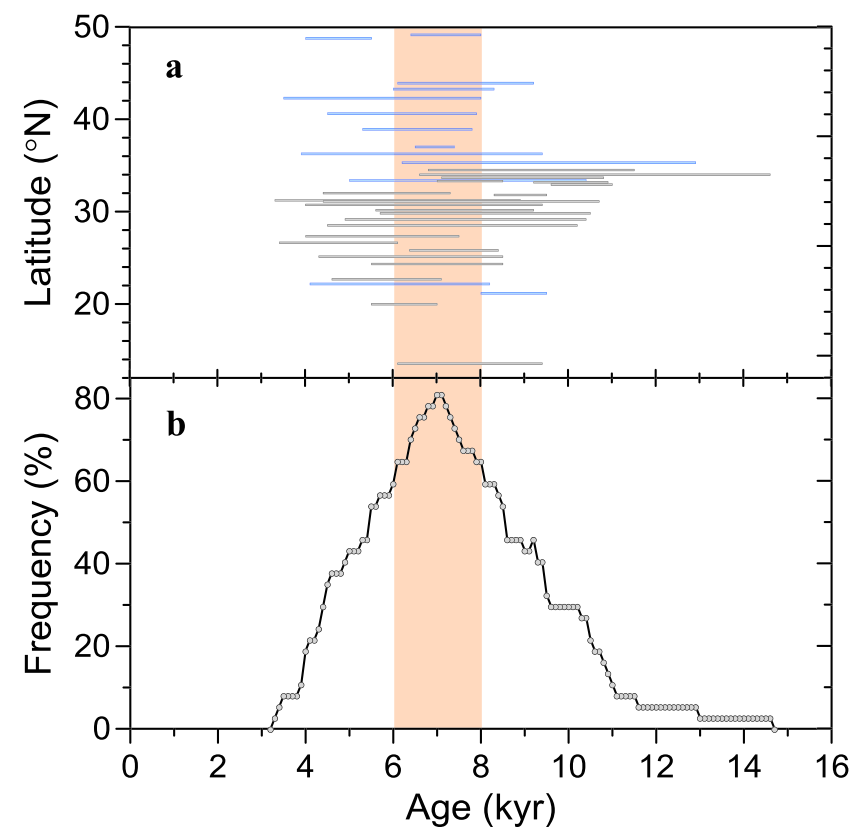

Figure 4. Comparison and synthesis of the Holocene Optimum reconstructed from previously published records. (a) Timing and duration of the Holocene Optimum determined from 37 previously published pollenbased palaeomonsoon records obtained from lake sediments (lake locations are provided in Figure 1 and Table S1). Blue indicates sites in the EASM region, and gray indicates sites in the ISM region. (b) Changes in distribution frequency of the timing of the Holocene Optimum with age. The duration of the Holocene Optimum (a) was first sliced at 100-year interval along the age axis, and the distribution frequency was then calculated as the number of intersection points divided by the total number of study sites (37).
The Holocene Optimum, as reflected by the pollen and geochemical records from Lake Bayanchagan in the EASM area (10.5-5.5 kyr BP), is roughly in phase with that obtained from Lake Tianchi in the ISM area (10-4 kyr BP) and is also consistent with recent findings from sites in northern China (Chen et al., 2016; Liu et al., 2015). Peak warmth at these two sites occurred roughly synchronously at 7.1-6.4 kyr BP. To enable a spatial comparison of the timing of the Holocene Optimum, we combined 37 previously published pollen-based palaeoclimatic records from lakes distributed across East Asia, from northern China to India (Figure 1 and Table S1). Although the timing of the Holocene Optimum in these records exhibits no regular spatial pattern from north to south (Figure 4a), over $60 \%$ of the sites were warm and wet during the interval of 8-6 kyr BP and over $80 \%$ at approximately 7 kyr BP (Figure $4 \mathrm{~b}$ ). These results agree well with our findings, suggesting the occurrence of synchronous changes in the intensity of the ISM and the EASM since the last deglaciation, with the Holocene Optimum occurring in the mid-Holocene.

The ISM is driven mainly by the north-south thermal contrast between the Indian Ocean and the Asian land mass, whereas the EASM is controlled by both the north-south thermal contrast between the Australian land mass and the western North Pacific and the east-west thermal contrast between the Asian continent and the Pacific Ocean (Wang et al., 2001). Synchronous changes in the intensity of the ISM and of the EASM indicate that a common mechanism-the latitudinal displacement of the Intertropical Convergence Zone (ITCZ) — controls the two main subsystems of the ASM. In general, the ITCZ migrates toward the warmer hemisphere (Schneider et al., 2014). The external forcing of a progressive increase in Northern Hemisphere $(\mathrm{NH})$ summer insolation from the last deglaciation to the early Holocene caused the ITCZ to shift gradually northward (Fleitmann et al., 2003; Schneider et al., 2014), thereby strengthening both the ISM and the EASM. Moreover, the increased atmospheric water vapor concentrations, driven by rising temperature, thermodynamically enhanced the monsoon rainfall (Mohtadi et al., 2016).

The peak in monsoon warmth and moisture (7.1-6.4 kyr BP) occurred some 3.9-4.6 kyr after the peak in insolation (Figure $3 \mathrm{~m}$ ), because the position of the ITCZ is also influenced by the extent of polar ice sheets (Chiang \& Bitz, 2005). As shown by records of the Laurentide ice sheet (Figure 3m) and global sea level (Figure 3n), the NH ice sheets were still relatively large at $11 \mathrm{kyr} \mathrm{BP}$, despite the occurrence of peak insolation, which impeded the northward shift of the ITCZ. From 11 to $6 \mathrm{kyr}$ BP, the NH ice sheets melted substantially, enabling a major northward shift of the ITCZ (Figure 3n) and the synchronous strengthening of the ISM and the EASM. After 6 kyr BP, even though NH ice volume remained constant, the decreasing NH insolation cooled the NH continents and impeded the continued northward shift of the ITCZ, thereby weakening both the ISM and the EASM.

\section{Conclusions}

Our results show that the ISM and the EASM varied synchronously since the last deglaciation and responded sensitively to the migration of the ITCZ. This was caused by the combined effects of external insolation forcing and internal $\mathrm{NH}$ ice volume forcing. In this context, $1.5-2{ }^{\circ} \mathrm{C}$ warming in the near-future (IPCC, 2013) will lead to decay of the extant $\mathrm{NH}$ ice sheets and hence to a further northward shift of the ITCZ. Thus, we propose that the ISM and the EASM will both intensify, and the Asian monsoon domain will become wetter. In this scenario, deciduous forest will increase in northern China, and the modern subalpine T. dumosa forest in the Hengduan Mountains of the ISM area will migrate upward. Given the average altitude of the Hengduan Mountains (3,000-4,000 m), the loss of habitat for T. dumosa and other alpine species will accelerate in a warmer world. 


\section{Acknowledgments}

This study was supported by the National Natural Science Foundation of China (grants 41725010 and 41472318), the National Key R \& D Program of China (grants 2017YFA0603403 and 2016YFA0600504), and Chinese Academy of Sciences (grants XDB26000000 and XDB31020404). We thank Chu, G., Liu, Q., Yang, X., Chai, Y., Wang, Y., and Wang, J. for field assistance and Kong, Z., Tang, L., and Luo Y. for laboratory assistance. We also thank Editor Valerie Trouet and the two anonymous reviewers for their constructive comments. Data are available from the Neotoma paleoecology database (www.neotomadb.org).

\section{References}

An, Z. S., Porter, S. C., Kutzbach, J. E., Wu, X. H., Wang, S. M., Liu, X. D., et al. (2000). Asynchronous Holocene optimum of the East Asian monsoon. Quaternary Science Reviews, 19(8), 743-762. https://doi.org/10.1016/S0277-3791(99)00031-1

Bennett, K. D. (2005). Psimpoll and pscomb programs for plotting and analysis, https://www.chrono.qub.ac.uk/psimpoll/psimpoll.html.

Berger, A., \& Loutre, M. F. (1991). Insolation values for the climate of the last 10 million years. Quaternary Science Reviews, 10(4), 297-317. https://doi.org/10.1016/0277-3791(91)90033-Q

Blaauw, M., \& Christen, J. A. (2011). Flexible paleoclimate age-depth models using an autoregressive gamma process. Bayesian Analysis, 6(3), 457-474. https://doi.org/10.1214/11-Ba618

Broecker, W. S., \& Putnam, A. E. (2013). Hydrologic impacts of past shifts of Earth's thermal equator offer insight into those to be produced by fossil fuel $\mathrm{CO}_{2}$. Proceedings of the National Academy of Sciences of the United States of America, 110(42), 16,710-16,715. https://doi. org/10.1073/pnas.1301855110

Chen, F. H., Chen, X. M., Chen, J. H., Zhou, A. F., Wu, D., Tang, L. Y., et al. (2014). Holocene vegetation history, precipitation changes and Indian Summer Monsoon evolution documented from sediments of Xingyun Lake, south-west China. Journal of Quaternary Science, 29(7), 661-674. https://doi.org/10.1002/jqs.2735

Chen, F. H., Xu, Q. H., Chen, J. H., Birks, H. J. B., Liu, J. B., Zhang, S. R., et al. (2015). East Asian summer monsoon precipitation variability since the last deglaciation. Scientific Reports, 5(1), 11186. https://doi.org/10.1038/srep11186

Chen, J. H., Rao, Z. G., Liu, J. B., Huang, W., Feng, S., Dong, G. H., et al. (2016). On the timing of the East Asian summer monsoon maximum during the Holocene-Does the speleothem oxygen isotope record reflect monsoon rainfall variability? Science China: Earth Sciences, 59(12), 2328-2338. https://doi.org/10.1007/s11430-015-5500-5

Cheng, B., Chen, F. H., \& Zhang, J. W. (2013). Palaeovegetational and palaeoenvironmental changes since the last deglacial in Gonghe Basin, northeast Tibetan Plateau. Journal of Geographical Sciences, 23(1), 136-146. https://doi.org/10.1007/s11442-013-0999-5

Cheng, H., Sinha, A., Wang, X. F., Cruz, F. W., \& Edwards, R. L. (2012). The Global Paleomonsoon as seen through speleothem records from Asia and the Americas. Climate Dynamics, 39(5), 1045-1062. https://doi.org/10.1007/s00382-012-1363-7

Chiang, J. C. H., \& Bitz, C. M. (2005). Influence of high latitude ice cover on the marine Intertropical Convergence Zone. Climate Dynamics, 25(5), 477-496. https://doi.org/10.1007/s00382-005-0040-5

Demske, D., Tarasov, P. E., Wunnemann, B., \& Riedel, F. (2009). Late glacial and Holocene vegetation, Indian monsoon and westerly circulation in the Trans-Himalaya recorded in the lacustrine pollen sequence from Tso Kar, Ladakh, NW India. Palaeogeography Palaeoclimatology Palaeoecology, 279(3-4), 172-185. https://doi.org/10.1016/j.palaeo.2009.05.008

Domros, M., \& Peng, G. (1988). The climate of China. Berlin: Springer. https://doi.org/10.1007/978-3-642-73333-8

Dong, J. G., Wang, Y. J., Cheng, H., Hardt, B., Edwards, R. L., Kong, X. G., et al. (2010). A high-resolution stalagmite record of the Holocene East Asian monsoon from Mt Shennongiia, central China. The Holocene, 20(2), 257-264. https://doi.org/10.1177/ 0959683609350393

Editorial Committee of Vegetation Map of China, CAS (2007). Vegetation of China and its Geographic Pattern, (p. 1228). Beijing: Geological Publishing House.

Enzel, Y., Ely, L. L., Mishra, S., Ramesh, R., Amit, R., Lazar, B., et al. (1999). High-resolution Holocene environmental changes in the Thar Desert, northwestern India. Science, 284(5411), 125-128. https://doi.org/10.1126/science.284.5411.125

Faegri, K., Kaland, P. E., \& Krzywinski, K. (2000). Textbook of pollen analysis (4th ed.). New Jersey: The Blackburn Press.

Fairbanks, R. G. (1990). The age and origin of the "younger Dryas climate event" in Greenland ice cores. Paleoceanography, 5(6), 937-948. https://doi.org/10.1029/PA005i006p00937

Fleitmann, D., Burns, S. J., Mudelsee, M., Neff, U., Kramers, J., Mangini, A., \& Matter, A. (2003). Holocene forcing of the Indian Monsoon recorded in a stalagmite from Southern Oman. Science, 300(5626), 1737-1739. https://doi.org/10.1126/science.1083130

Grant, K. M., Rohling, E. J., Bar-Matthews, M., Ayalon, A., Medina-Elizalde, M., Ramsey, C. B., et al. (2012). Rapid coupling between ice volume and polar temperature over the past 150,000 years. Nature, 491(7426), 744-747. https://doi.org/10.1038/nature11593

Guiot, J., \& Goeury, C. (1996). PPPBASE, a software for statistical analysis of paleoecological and paleoclimatological data. Dendrochronologia, 14, 295-300.

Herzschuh, U., Borkowski, J., Schewe, J., Mischke, S., \& Tian, F. (2014). Moisture-advection feedback supports strong early-to-mid Holocene monsoon climate on the eastern Tibetan Plateau as inferred from a pollen-based reconstruction. Palaeogeography Palaeoclimatology Palaeoecology, 402, 44-54. https://doi.org/10.1016/j.palaeo.2014.02.022

Herzschuh, U., Kramer, A., Mischke, S., \& Zhang, C. J. (2009). Quantitative climate and vegetation trends since the late glacial on the northeastern Tibetan Plateau deduced from Koucha Lake pollen spectra. Quaternary Research, 71(2), 162-171. https://doi.org/10.1016/j. yqres.2008.09.003

Herzschuh, U., Winter, K., Wunnemann, B., \& Li, S. J. (2006). A general cooling trend on the central Tibetan Plateau throughout the Holocene recorded by the Lake Zigetang pollen spectra. Quaternary International, 154-155, 113-121. https://doi.org/10.1016/j quaint.2006.02.005

Hong, Y. T., Hong, B., Lin, Q. H., Shibata, Y., Hirota, M., Zhu, Y. X., et al. (2005). Inverse phase oscillations between the East Asian and Indian ocean summer monsoons during the last 12000 years and paleo-El Niño. Earth and Planetary Science Letters, 231(3-4), 337-346. https://doi.org/10.1016/j.epsl.2004.12.025

IPCC (2013). Climate change 2013: The physical science basis. Cambridge, UK: Cambridge University Press.

Jarvis, D. I. (1993). Pollen evidence of changing Holocene monsoon climate in Sichuan-Province, China. Quaternary Research, 39(3), 325-337. https://doi.org/10.1006/qres.1993.1039

Jiang, S. Z. (2013). Meteorology and climatology. Beijing: Science Press.

Jiang, W. Y., Guo, Z. T., Sun, X. J., Wu, H. B., Chu, G. Q., Yuan, B. Y., et al. (2006). Reconstruction of climate and vegetation changes of Lake Bayanchagan (Inner Mongolia): Holocene variability of the East Asian monsoon. Quaternary Research, 65(3), 411-420. https://doi.org/ 10.1016/j.yqres.2005.10.007

Jiang, W. Y., \& Liu, T. S. (2007). Timing and spatial distribution of mid-Holocene drying over northern China: Response to a southeastward retreat of the East Asian Monsoon. Journal of Geophysical Research, 112, D24111. https://doi.org/10.1029/2007jd009050

Kramer, A., Herzschuh, U., Mischke, S., \& Zhang, C. J. (2010). Holocene treeline shifts and monsoon variability in the Hengduan Mountains (southeastern Tibetan Plateau), implications from palynological investigations. Palaeogeography Palaeoclimatology Palaeoecology, 286(1-2), 23-41. https://doi.org/10.1016/j.palaeo.2009.12.001

Lee, C. Y., Liew, P. M., \& Lee, T. Q. (2010). Pollen records from southern Taiwan: Implications for East Asian summer monsoon variation during the Holocene. The Holocene, 20(1), 81-89. https://doi.org/10.1177/0959683609348859 
Leipe, C., Demske, D., Tarasov, P. E., \& Members, H. P. (2014). A Holocene pollen record from the northwestern Himalayan lake Tso Moriri: Implications for palaeoclimatic and archaeological research. Quaternary International, 348, 93-112. https://doi.org/10.1016/j. quaint.2013.05.005

Lenoir, J., Gegout, J. C., Marquet, P. A., de Ruffray, P., \& Brisse, H. (2008). A significant upward shift in plant species optimum elevation during the 20th century. Science, 320(5884), 1768-1771. https://doi.org/10.1126/science.1156831

Li, C. H., Wu, Y. H., \& Hou, X. H. (2011). Holocene vegetation and climate in Northeast China revealed from Jingbo Lake sediment. Quaternary International, 229(1-2), 67-73. https://doi.org/10.1016/j.quaint.2009.12.015

Li, L., Yang, J.-N., Cui, K., Trotter, R. T., Li, Z.-H., Li, G.-Q., \& Liao, S.-X. (2013). Strobili and seed characteristics of Tsuga dumosa and its relationship with environmental factors. Chinese Journal of Plant Ecology, 37(9), 820-829.

Liu, J. B., Chen, J. H., Zhang, X. J., Li, Y., Rao, Z. G., \& Chen, F. H. (2015). Holocene East Asian summer monsoon records in northern China and their inconsistency with Chinese stalagmite delta O-18 records. Earth-Science Reviews, 148, 194-208. https://doi.org/10.1016/ j.earscirev.2015.06.004

Ma, Q. F., Zhu, L. P., Lu, X. M., Guo, Y., Ju, J. T., Wang, J. B., et al. (2014). Pollen-inferred Holocene vegetation and climate histories in Taro co, southwestern Tibetan Plateau. Chinese Science Bulletin, 59(31), 4101-4114. https://doi.org/10.1007/s11434-014-0505-1

Marcott, S. A., Shakun, J. D., Clark, P. U., \& Mix, A. C. (2013). A reconstruction of regional and global temperature for the past 11,300 years Science, 339(6124), 1198-1201. https://doi.org/10.1126/science.1228026

Maxwell, A. L. (2001). Holocene monsoon changes inferred from lake sediment pollen and carbonate records, northeastern Cambodia. Quaternary Research, 56(3), 390-400. https://doi.org/10.1006/qres.2001.2271

McGee, D., Donohoe, A., Marshall, J., \& Ferreira, D. (2014). Changes in ITCZ location and cross-equatorial heat transport at the Last Glacial Maximum, Heinrich Stadial 1, and the mid-Holocene. Earth and Planetary Science Letters, 390, 69-79. https://doi.org/10.1016/j. epsl.2013.12.043

Mohtadi, M., Prange, M., \& Steinke, S. (2016). Palaeoclimatic insights into forcing and response of monsoon rainfall. Nature, 533(7602), 191-199. https://doi.org/10.1038/nature17450

Peltier, W. R., \& Fairbanks, R. G. (2006). Global glacial ice volume and Last Glacial Maximum duration from an extended Barbados sea level record. Quaternary Science Reviews, 25(23-24), 3322-3337. https://doi.org/10.1016/j.quascirev.2006.04.010

Porter, S. C. (2001). Snowline depression in the tropics during the Last Glaciation. Quaternary Science Reviews, $20(10), 1067-1091$.

Prasad, S., Anoop, A., Riedel, N., Sarkar, S., Menzel, P., Basavaiah, N., et al. (2014). Prolonged monsoon droughts and links to Indo-Pacific warm pool: A Holocene record from Lonar Lake, central India. Earth and Planetary Science Letters, 391, 171-182. https://doi.org/ 10.1016/j.epsl.2014.01.043

Prentice, I. C., Guiot, J., Huntley, B., Jolly, D., \& Cheddadi, R. (1996). Reconstructing biomes from palaeoecological data: A general method and its application to European pollen data at 0 and 6 ka. Climate Dynamics, 12(3), 185-194. https://doi.org/10.1007/ s003820050102

Quamar, M. F., \& Chauhan, M. S. (2012). Late Quaternary vegetation, climate as well as lake-level changes and human occupation from Nitaya area in Hoshangabad District, southwestern Madhya Pradesh (India), based on pollen evidence. Quaternary International, 263, 104-113. https://doi.org/10.1016/j.quaint.2012.01.001

Schneider, T., Bischoff, T., \& Haug, G. H. (2014). Migrations and dynamics of the intertropical convergence zone. Nature, 513(7516), 45-53. https://doi.org/10.1038/nature13636

Shen, J., Jones, R. T., Yang, X. D., Dearing, J. A., \& Wang, S. M. (2006). The Holocene vegetation history of Lake Erhai, Yunnan province southwestern China: The role of climate and human forcings. The Holocene, 16(2), 265-276. https://doi.org/10.1191/ 0959683606hl923rp

Shen, J., Liu, X. Q., Wang, S. M., \& Matsumoto, R. (2005). Palaeoclimatic changes in the Qinghai Lake area during the last 18,000 years. Quaternary International, 136(1), 131-140. https://doi.org/10.1016/j.quaint.2004.11.014

Shuman, B., Bartlein, P. J., \& Webb, T. (2005). The magnitudes of millennial- and orbital-scale climatic change in eastern North America during the Late Quaternary. Quaternary Science Reviews, 24(20-21), 2194-2206. https://doi.org/10.1016/j. quascirev.2005.03.018

Singh, G., Wasson, R. J., \& Agrawal, D. P. (1990). Vegetational and seasonal climatic changes since the Last Full Glacial in the Thar Desert, Northwestern India. Review of Palaeobotany and Palynology, 64(1-4), 351-358. https://doi.org/10.1016/0034-6667(90)90151-8

Stebich, M., Rehfeld, K., Schlutz, F., Tarasov, P. E., Liu, J. Q., \& Mingram, J. (2015). Holocene vegetation and climate dynamics of NE China based on the pollen record from Sihailongwan Maar Lake. Quaternary Science Reviews, 124, 275-289. https://doi.org/10.1016/j. quascirev.2015.07.021

Sun, W. W., Zhang, E. L., Shen, J., Chen, R., \& Liu, E. F. (2016). Black carbon record of the wildfire history of western Sichuan Province in China over the last $12.8 \mathrm{ka}$. Frontiers of Earth Science, 10(4), 634-643. https://doi.org/10.1007/s11707-015-0546-Z

Sun, X. J., Du, N. Q., Chen, Y. S., Gu, Z. Y., Liu, J. Q., \& Yuan, B. Y. (1993). Holocene palynological records in Lake Selincuo, Northern Xizang. Acta Botanica Sinica, 35(12), 943-950.

Tang, L.-Y., Chen, C.-M., Liu, K.-B., \& Overpeck, J. T. (2000). Climatic and hydrological changes in the southeastern Qinghai-Tibetan Plateau during the past 18000 years. Acta Micropalaeontologica Sinica, 17(2), 113-124.

VanCampo, E., Cour, P., \& Hang, S. X. (1996). Holocene environmental changes in Bangong Co basin (western Tibet).2. The pollen record. Palaeogeography Palaeoclimatology Palaeoecology, 120(1-2), 49-63. https://doi.org/10.1016/0031-0182(95)00033-X

VanCampo, E., \& Gasse, F. (1993). Pollen-inferred and diatom-inferred climatic and hydrological changes in Sumxi Co Basin (Western Tibet) since 13,000 yr BP. Quaternary Research, 39(3), 300-313. https://doi.org/10.1006/qres.1993.1037

Wang, B., Wu, R. G., \& Lau, K. M. (2001). Interannual variability of the Asian summer monsoon: Contrasts between the Indian and the western North Pacific-east Asian monsoons. Journal of Climate, 14(20), 4073-4090. https://doi.org/10.1175/1520-0442(2001)014<4073 Ivotas $>2.0 . \mathrm{Co} ; 2$

Wang, F., Chien, N., Zhang, Y., \& Yang, H. (1997). Pollen flora of China (p. 461). Beijing: Science Press.

Wang, S. Y., Lu, H. Y., Liu, J. Q., \& Negendank, J. F. W. (2007). The early Holocene optimum inferred from a high-resolution pollen record of Huguangyan Maar Lake in southern China. Chinese Science Bulletin, 52(20), 2829-2836. https://doi.org/10.1007/s11434-007$0419-2$

Wang, Y. B., Liu, X. Q., \& Herzschuh, U. (2010). Asynchronous evolution of the Indian and East Asian Summer Monsoon indicated by Holocene moisture patterns in monsoonal central Asia. Earth-Science Reviews, 103(3-4), 135-153. https://doi.org/10.1016/j. earscirev.2010.09.004

Weijers, J. W. H., Schefuss, E., Schouten, S., \& Damste, J. S. S. (2007). Coupled thermal and hydrological evolution of tropical Africa over the last deglaciation. Science, 315(5819), 1701-1704. https://doi.org/10.1126/science.1138131 
Wen, R. L., Xiao, J., Chang, Z. G., Zhai, D. Y., Xu, Q. H., Li, Y. C., \& Itoh, S. (2010). Holocene precipitation and temperature variations in the East Asian monsoonal margin from pollen data from Hulun Lake in northeastern Inner Mongolia, China. Boreas, 39(2), 262-272. https://doi.org/10.1111/j.1502-3885.2009.00125.x

Wen, R. L., Xiao, J. L., Fan, J. W., Zhang, S. R., \& Yamagata, H. (2017). Pollen evidence for a mid-Holocene East Asian summer monsoon maximum in northern China. Quaternary Science Reviews, 176, 29-35. https://doi.org/10.1016/j.quascirev.2017.10.008

Wischnewski, J., Mischke, S., Wang, Y. B., \& Herzschuh, U. (2011). Reconstructing climate variability on the northeastern Tibetan Plateau since the last Lateglacial-A multi-proxy, dual-site approach comparing terrestrial and aquatic signals. Quaternary Science Reviews, 30(1-2), 82-97. https://doi.org/10.1016/j.quascirev.2010.10.001

Wunnemann, B., Demske, D., Tarasov, P., Kotlia, B. S., Reinhardt, C., Bloemendal, J., et al. (2010). Hydrological evolution during the last $15 \mathrm{kyr}$ in the Tso Kar lake basin (Ladakh, India), derived from geomorphological, sedimentological and palynological records. Quaternary Science Reviews, 29(9-10), 1138-1155. https://doi.org/10.1016/j.quascirev.2010.02.017

Xiao, J. L., Xu, Q. H., Nakamura, T., Yang, X. L., Liang, W. D., \& Inouchi, Y. (2004). Holocene vegetation variation in the Daihai Lake region of north-central China: A direct indication of the Asian monsoon climatic history. Quaternary Science Reviews, 23(14-15), 1669-1679. https://doi.org/10.1016/j.quascirev.2004.01.005

Xiao, X. Y., Haberle, S. G., Shen, J., Yang, X. D., Han, Y., Zhang, E. L., \& Wang, S. M. (2014). Latest Pleistocene and Holocene vegetation and climate history inferred from an alpine lacustrine record, northwestern Yunnan Province, southwestern China. Quaternary Science Reviews, 86, 35-48. https://doi.org/10.1016/j.quascirev.2013.12.023

Xiao, X. Y., Shen, J. I., Haberle, S. G., Han, Y., Xue, B., Zhang, E. L., et al. (2015). Vegetation, fire, and climate history during the last 18 500 cal a BP in south-western Yunnan Province, China. Journal of Quaternary Science, 30(8), 859-869. https://doi.org/10.1002/jqs.2824

Yu, G., Chen, X., Ni, J., Cheddadi, R., Guiot, J., Han, H., et al. (2000). Palaeovegetation of China: A pollen data-based synthesis for the midHolocene and last glacial maximum. Journal of Biogeography, 27(3), 635-664. https://doi.org/10.1046/j.1365-2699.2000.00431.x

Zhang, E. L., Wang, Y. B., Sun, W. W., \& Shen, J. (2016). Holocene Asian monsoon evolution revealed by a pollen record from an alpine lake on the southeastern margin of the Qinghai-Tibetan Plateau, China. Climate of the Past, 12(2), 415-427. https://doi.org/10.5194/cp12-415-2016

Zhang, H. L., Yu, K. F., Zhao, J. X., Feng, Y. X., Lin, Y. S., Zhou, W., \& Liu, G. H. (2013). East Asian Summer Monsoon variations in the past 12.5 ka: High-resolution delta O-18 record from a precisely dated aragonite stalagmite in central China. Journal of Asian Earth Sciences, 73, 162-175. https://doi.org/10.1016/j.jseaes.2013.04.015

Zhou, X., Sun, L. G., Zhan, T., Huang, W., Zhou, X. Y., Hao, Q. Z., et al. (2016). Time-transgressive onset of the Holocene Optimum in the East Asian monsoon region. Earth and Planetary Science Letters, 456, 39-46. https://doi.org/10.1016/j.epsl.2016.09.052 